\title{
FAKTOR SOSIAL PSIKOLOGIS PERILAKU MENGGUNAKAN HELM PADA PENGENDARA SEPEDA MOTOR: STUDI DI WILAYAH DEPOK
}

\section{Social Psychological Factors of Using Helmets Behavior in Motorcycle Riders: Study in Depok Area}

\author{
Guritnaningsih \\ Fakultas Pesikologi \\ Universitas Indonesia \\ Kampus Baru UI \\ Depok, Jawa Barat \\ gurit_santoso@yahoo.com
}

\author{
Dewi Maulina \\ Fakultas Pesikologi \\ Universitas Indonesia \\ Kampus Baru UI \\ Depok, Jawa Barat \\ dewi.maulina@ui.ac.id
}

\author{
Ermanda Siregar \\ Departemen Teknik Sipil \\ Universitas Indonesia \\ Kampus Baru UI \\ Depok, Jawa Barat \\ esiregar@ui.ac.id
}

\begin{abstract}
An impact to the head when it is not protected by a helmet generally results in brain injury and may result in death. The current study aimed to identify the psychosocial factors that play a role in helmet wearing behavior among motorcyclists. A mixed-method approach was used on a sample of active motorcycle riders in Depok area who are in early and middle adulthood. Data were collected using a questionnaire and a Focused Group Discussion. The results showed a difference between adults under 25 years and adults over 25 years in their attitude towards helmet use. Level of education and attitude were also both found to be significant predictors of helmet use. Findings of the study imply the need for a more structured effort to build a positive attitude towards helmet use, especially among younger motorcycle riders.
\end{abstract}

Key words: helmet wearing behavior, attitude, subjective norms, perceived behavior control, motorcyclist

\begin{abstract}
Abstrak
Benturan pada kepala yang tidak dilindungi oleh helm umumnya menyebabkan kerusakan pada otak dan berujung pada kematian. Penelitian ini bertujuan untuk mengidentifikasi faktor sosial psikologis yang berperan pada perilaku menggunakan helm pada pengendara sepeda motor. Pendekatan yang digunakan adalah mixed-method, dengan sampel pengendara sepeda motor aktif di wilayah Depok, yang berusia dewasa muda dan dewasa menengah. Pengumpulan data dilakukan dengan menggunakan kuesioner dan diskusi kelompok terfokus (Focus Group Discussion) . Hasil penelitian ini menunjukkan bahwa terdapat perbedaan sikap terhadap penggunaan helm antara pengendara sepeda motor berusia di bawah 25 tahun dan yang berusia di atas 25 tahun . Ditemukan juga bahwa tingkat pendidikan dan sikap merupakan prediktor yang signifikan terhadap penggunaan helm. Implikasi penelitian ini adalah dilakukannya upaya yang lebih terstruktur untuk pembentukan sikap positif pada para pengendara sepeda moto $r$ terutama pengendara usia muda.
\end{abstract}

Kata kunci: perilaku menggunakan helm, sikap, norma subjektif, persepsi kontrol perilaku, pengendara sepeda motor

\section{PENDAHULUAN}

Jumlah sepeda motor meningkat dengan pesat pada 5 tahun terakhir. Jika pada tahun 2012 jumlah sepeda motor di Indonesia tercatat kurang dari 80 juta unit, pada tahun 2013 meningkat menjadi 84.732.652 unit, dan mulai tahun 2016 telah melebihi angka 100 juta unit, yaitu 105.150.082 unit (BPS, 2017). Jumlah sepeda motor mencakup sekitar $82 \%$ dari keseluruhan kendaraan bermotor yang ada di Indonesia. Jumlah sepeda motor yang meningkat dengan pesat telah membawa berbagai dampak di jalan, seperti pelanggaran 
peraturan lalu lintas, melawan arah, mengebut, menerobos lampu merah, dan maraknya pengendara sepeda motor di bawah umur. Berbagai kelalaian, pelanggaran, dan perilaku mengendara yang tergolong berbahaya (agresif) tersebut telah mengakibatkan tingginya angka kecelakaan yang melibatkan sepeda motor di jalan, baik di daerah perkotaan maupun di daerah pedesaan atau di pinggiran kota.

Telah terjadi peningkatan angka kecelakaan yang sangat mencolok dari tahun ke tahun (Suwiknyo, 2015; Marhaenjati, 2016; Suwannaporn, Hongsranagon, Havanond, 2017). Selain masalah tingginya peningkatan dalam jumlah kejadian kecelakaan, masalah yang juga memprihatinkan adalah fatalitas akibat terjadinya kecelakaan. Tercatat rata-rata ratio fatalitas untuk 100.000 populasi pada tahun 2016 sebesar 10.47 (dikutip dari Panduan Hibah Traffic Accident Research Center, 2018, hal. 3). Angka ini menunjukkan bahwa dari 100.000 orang dalam populasi akan terjadi kecelakaan yang diikuti oleh kematian sebesar (10-11) orang.

Salah satu penyebab fatalitas kecelakaan yang dialami oleh pengendara sepeda motor adalah cedera pada kepala. Pada umumnya cedera pada kepala terjadi akibat pengendara sepeda motor tidak menggunakan helm. Sebagaimana dikemukakan oleh Nayazi (Kompas.com, 2018), pada tahun 2017 terdapat sekitar 5.000 orang korban meninggal akibat tidak menggunakan helm.

Sesungguhnya penggunaan helm merupakan suatu kewajiban yang diatur dalam UndangUndang untuk ditaati oleh pengendara maupun penumpang sepeda motor. Pada Pasal 57 ayat (1) jo ayat (2), UU No. 22 Tahun 2009 tentang Lalu Lintas dan Angkutan Jalan dikemukakan bahwa:

1. Setiap Kendaraan Bermotor yang dioperasikan di Jalan wajib dilengkapi dengan perlengkapan Kendaraan Bermotor;

2. Perlengkapan sebagaimana dimaksud pada ayat (1) bagi Sepeda Motor berupa helm Standar Nasional Indonesia (SNI).

Pasal 106 ayat (8) UU No. 22/2009 juga mengatur bahwa setiap orang yang mengemudikan sepeda motor dan penumpang sepeda motor wajib mengenakan helm yang memenuhi Standar Nasional Indonesia.

Mengacu pada peraturan dalam Undang-Undang tersebut, setiap pengendara sepeda motor yang tidak menggunakan helm dapat digolongkan sebagai melakukan pelanggaran. Dalam kajian psikologi lalu lintas, perilaku tidak menggunakan helm ketika mengendarai sepeda motor di jalan termasuk sebagai perilaku berisiko yang tergolong sebagai violation. Adapun yang dimaksud dengan violation adalah perilaku berisiko yang dilakukan pengendara sepeda motor dengan sengaja atau dengan sadar bahwa perilakunya merupakan hal yang berbahaya atau ilegal namun tetap dilakukan (Chang \& Yeh, 2007).

Penggunaan helm masih rendah pada negara-negara berkembang dibandingkan dengan di negara maju. Di Cina misalnya, penggunaan helm hanya mencapai $34 \%$ (Suwannaporn, Hongsranagon, Havanond, 2017), demikian juga dii Iran sekitar $35 \%$ (Seyed Nabiollah Mirhossini, Seyed Rasoul Davoodi, Majid Azimmohseni, 2018).

Gambaran yang tidak jauh berbeda juga ditemukan di Indonesia. Di berbagai daerah perkotaan maupun pedesaan di Indonesia, sebagaimana juga di wilayah Depok, cukup banyak ditemui pengendara sepeda motor ataupun penumpangnya yang tidak menggunakan helm. Perilaku ini tentu sangat berbahaya dan berpotensi besar mengganggu 
keselamatan di jalan mengingat kepadatan kendaraan di wilayah Depok sebagai remote area dari Jakarta tergolong tinggi.

Hasil studi di Iran tentang penggunaan helm menunjukkan bahwa kesadaran akan peraturan lalu lintas menjadi faktor yang besar perannya untuk ikut menentukan penggunaan helm, sementara persepsi akan adanya penegakan aturan kurang berperan. Faktor lain yang juga berperan adalah lama perjalanan per hari, pengalaman mengendarai sepeda motor, dan jenis pekerjaan (Haqverdi, Seyedabrishami, \& Groeger, 2015). Selain peran kesadaran akan peraturan lalu lintas, yang juga dapat menjelaskan tentang penggunaan helm adalah faktor sikap dan intensi untuk menggunakan helm.

Uraian tersebut menunjukkan adanya hasil penelitian yang berbeda-beda pada tempat yang berbeda-beda. Di Indonesia sendiri terlihat begitu banyaknya pelanggaran penggunaan helm yang dilakukan oleh para pengendara sepeda motor, sehingga perlu dikaji faktor sosial psikologis yang menentukan penggunaan helm.

Dari penelitian ini diharapkan dapat diketahui faktor-faktor yang berperan dalam penggunaan helm pada pengendara sepeda motor di Indonesia. Hasil penelitian diharapkan dapat dimanfaatkan untuk menentukan solusi yang memadai bagi pihak kepolisian untuk meningkatkan ketertiban penggunaan helm pengandara sepeda motor.

\section{Faktor Sosial Psikologis Yang Mendasari Perilaku}

Menurut Theory of Planned Behavior (TPB) perilaku individu dapat dijelaskan melalui 4 komponen, yaitu sikap (attitude), norma subjektif (subjective norms), persepsi mengenai kontrol diri terhadap perilaku (Perceived behavior control, dan intensi untuk melakukan perilaku (Fishbein \& Ajzen, 1975). Jika teori TPB diaplikasikan ke dalam perilaku menggunakan helm, dapat dikatakan bahwa perilaku pengendara sepeda motor untuk menggunakan helm diwarnai oleh sikapnya terhadap penggunaan helm, persepsi individu tentang norma yang berlaku bagi orang-orang yang berperan dalam hidupnya tentang penggunaan helm, persepsi individu tentang kemampuan mengendalikan dirinya untuk menggunakan helm, dan niat untuk menggunakan helm.

Hasil-hasil penelitian pada masyarakat dengan budaya timur, seperti Indonesia, Malaysia, dan Thailand menunjukkan bahwa perilaku individu banyak dipengaruhi oleh lingkungan sosial. Orang-orang yang signifikan dalam kehidupan individu, seperti orangtua, teman, dan anggota kelompoknya sangat berpengaruh terhadap perilaku individu. Individu cenderung mengikuti (confirm) pada pandangan dan apa yang ditampilkan oleh orangorang dalam kehidupannya (Caldini and Trost 1998; Zhou et al. 2009, dalam Sukor dan Fujii, 2011). John \& Najafi (2011), dalam penelitiannya pada pengguna sepeda, menemukan bahwa penggunaan helm ditentukan oleh faktor norma subjektif, yaitu sejauh mana individu mempersepsikan adanya tekanan dari keluarga dan teman untuk tidak menggunakan atau menggunakan helm. Peran pengaruh lingkungan sosial (social norms) dalam mendorong individu untuk menggunakan helm juga ditemukan dalam penelitian Yazdanpanah, Seyedabrishami dan Quchaniyan (2015).

Hasil penelitian Brijs, Kris, Brijs, Tom, Sann, Socheata, Anh, Trinh Tú, Wets, Geert, \& Ruiter, Robert A.C. (2014) menunjukkan bahwa penggunaan helm lebih ditentukan oleh faktor perceived behavior control terkait faktor situasional tertentu, misalnya mengendara dalam jarak dekat, mengendara pada malam hari, atau pada saat menggunakan pakaian tertentu. 


\section{METODE PENELITIAN}

\section{Partisipan}

Partisipan pada penelitian ini adalah pengendara aktif sepeda motor berusia remaja (minimal 17 tahun) hingga usia dewasa (maksimum 60 tahun) yang biasa mengendarai sepeda motornya di jalan di wilayah Depok. Usia minimal 17 tahun ditetapkan dengan pertimbangan bahwa pengendara sudah berada pada usia yang secara legal diizinkan untuk memiliki Surat Izin Mengemudi (SIM) C.

Partisipan yang menjadi sampel dalam penelitian ini diperoleh dengan menggunakan teknik accidental sampling. Partisipan berada pada rentang usia antara (18 - 59) tahun, dengan rata-rata usia 23,74 tahun (Mean=2374 tahun dan $\mathrm{SD}=7,45$ tahun).

\section{Tipe Penelitian}

Penelitian ini merupakan penelitian dengan pendekatan mixed-method. Pendekatan kuantitatif dilakukan dengan melakukan pengumpulan informasi melalui penyebaran kuesioner secara online. Pendekatan kualitatif dilakukan dengan Focus Group discussion (FGD).

\section{Instrumen Pengumpulan Data}

Untuk studi kuantitatif digunakan sebuah kuesioner yang terdiri atas 2 bagian. Bagian pertama berisi data pribadi, seperti usia, jenis kelamin, pendidikan, pekerjaan, jenis sepeda motor yang dimiliki, dan frekuensi mengendarai motor dalam seminggu. Bagian kedua berisi item-item pertanyaan tentang faktor sosial psikologis yang berperan dalam perilaku menggunakan helm, yang terdiri atas 3 dimensi, yaitu dimensi sikap, dimensi norma subjektif, dan perceived behavior control (PBC).

1. Sikap (attitude) terhadap penggunaan helm

Pada studi ini sikap terhadap penggunaan helm didefinisikan sebagai sekumpulan pengetahuan atau keyakinan (belief) dan evaluasi individu (suka/tidak suka; mendukung/tidak mendukung) terhadap penggunaan helm.

2. Norma subjektif (subjective norms)

Norma subjektif diartikan sebagai persepsi pengendara sepeda motor tentang adanya tekanan sosial (harapan atau dorongan dari orang-orang yang berpengaruh dalam kehidupannya (significant others)) mengenai penggunaan helm oleh pengendara sepeda motor.

3. Persepsi kontrol perilaku (Perceived behavior control/PBC)

PBC adalah persepsi tentang peluangnya untuk menggunakan helm. Dalam PBC terkandung persepsi tentang faktor-faktor internal dan faktor eksternal yang memungkinkannya untuk menggunakan helm. Yang dimaksud faktor eksternal misalnya adalah keyakinan individu mengenai ketersediaan sumberdaya berupa ketersediaan atau kepemilikan helm, ketersediaan uang untuk membeli, dan kemauan membersihkan helm. Yang dimaksud faktor internal misalnya adalah keterampilan untuk mengendarai sepeda motor dengan menggunakan helm dan ketersediaan waktu.

Hasil analisis reliabilitas terhadap instrumen yang mengukur faktor sosial psikologis menunjukkan bahwa alat ukur yang digunakan cukup reliabel (alpha $=0,86$ ).

Untuk pengumpulan data dengan teknik Focus Group Discussion (FGD) disusun pedoman diskusi untuk menggali berbagai informasi sosial psikologis yang merupakan faktor 
pendukung dan penghambat penggunaan helm, dan pandangan para responden terhadap peraturan penggunaan helm.

\section{Analisis data}

Data kuantitatif yang terkumpul diolah dengan teknik Analysis of Variance (ANOVA), dan Multiple Regression. Sedangkan data yang diperoleh melalui teknik FGD dianalisis secara kualitatif.

\section{HASIL PENELITIAN}

\section{Analisis Kuantitatif}

\section{Gambaran partisipan}

Data demografis dapat dilihat pada Tabel 1, yang menunjukkan persentase pengendara sepeda motor pria $(56,7 \%)$ lebih besar dibandingkan pengendara sepeda motor wanita (43,3\%). Dari segi pendidikan, sekitar duapertiga partisipan adalah lulusan SMA atau sederajad, diikuti dengan pendidikan S1 (24,6\%). Mereka umumnya adalah mahasiswa atau pelajar, dan hanya sekitar seperlima responden $(23,1 \%)$ yang merupakan pegawai swasta.

Tabel 1. Data demografis partisipan $(\mathrm{N}=134)$

\begin{tabular}{llcc}
\hline & Aspek & Frekuensi & Persentase \\
\hline Jenis kelamin & Pria & 76 & 56,7 \\
& Wanita & 58 & 43,3 \\
\hline Pendidikan & SMP/ sederajad & 1 & 0,8 \\
& SMA/ sederajad & 85 & 63,4 \\
& Diploma & 12 & 9,0 \\
& S1 & 33 & 24,6 \\
& S2/S3 & 3 & 2,2 \\
\hline \multirow{2}{*}{ Pekerjaan } & Mahasiswa/ pelajar & 93 & 69,4 \\
& Karyawan swasta & 31 & 23,1 \\
& Lain-lain & 10 & 7,5 \\
\hline
\end{tabular}

Pada Tabel 2 terlihat bahwa data yang terkait dengan penggunaan sepeda motor menunjukkan bahwa sebagian besar partisipan mengendarai sepeda motor jenis matic (74,6\%), dengan (90-125) cc dan 90 cc. Jarak tempuh partisipan cukup bervariasi, namun lebih banyak yang menempuh jarak kurang dari $20 \mathrm{~km}(47,0 \%)$ atau antara (20-40) km per hari $(33,6 \%)$. Sebagian besar partisipan mengendarai sepeda motornya di jalan, baik di daerah pingginran kota $(48,5 \%)$ atau di daerah pusat kota $(44,0 \%)$. Ternyata terdapat hampir $10 \%$ partisipan yang tidak memiliki Surat Ijin Mengemudi (SIM) C walaupun mereka mengendarai sepedanmotor. Sekitar $10 \%$ partisipan juga yang tidak tertib menggunakan helm ketika mengendarai sepeda motor. 
Tabel 2. Data terkait dengan penggunaan sepeda motor $(\mathrm{N}=134)$

\begin{tabular}{llcc}
\hline & Aspek & Frekuensi & Persentase \\
\hline Jenis motor & Motor Bebek & 31 & 23,1 \\
& Motor Matic & 100 & 74,6 \\
& Scooter & 2 & 1,5 \\
\hline CC sepeda motor & $125 \mathrm{cc}+$ & 28 & 1,6 \\
& $90 \mathrm{cc}$ & 7 & 22,4 \\
& $90-125$ cc & 97 & 72,4 \\
& Tidak mengisi & 2 & 1,6 \\
\hline Jarak tempuh & 20 km/kurang & 63 & 47,0 \\
& $20-40$ km & 45 & 33,6 \\
\hline Jenis jalan yang umumnya dilalui & Kompleks/perumahan & 26 & 19,4 \\
\hline & Jalan raya pinggiran kota & 10 & 7,5 \\
& Jalan raya di pusat kota & 65 & 48,5 \\
\hline Kepemilikan SIM & SIM A / SIM B & 59 & 44,0 \\
\hline SIM C & 5 & 3,7 \\
& SIM C + SIM A & 59 & 44,0 \\
& Tidak ada & 62 & 46,3 \\
\hline Frekuensi menggunakan satu minggu terakhir & Jarang & 8 & 6,0 \\
\hline & Kadang-kadang & 5 & 3,7 \\
& Sering & 9 & 6,7 \\
& Selalu & 30 & 67,2 \\
\hline
\end{tabular}

\section{Penggunaan helm}

Ditinjau dari segi demografis, terlihat adanya perbedaan sikap terhadap penggunaan helm yang signifikan antara pengendara berusia dewasa muda (di bawah 25 tahun) dan usia 25 tahun ke atas. Analisis dipisahkan antara kelompok usia di bawah 25 tahun dan usia 25 tahun ke atas, karena usia di bawah 25 tahun masih merupakan usia remaja akhir dan mereka masih cenderung menampilkan perilaku mengendara secara agresif. Kelompok usia 25 tahun ke bawah memiliki sikap terhadap penggunaan helm yang negatif dibandingkan pengendara sepeda motor kelompok usia di atas 25 tahun $(t(132)=-3,830$, $p<0,0001)$. Artinya, kelompok usia di bawah 25 tahun kurang memiliki keyakinan akan manfaat penggunaan helm dibandingkan kelompok usia 25 tahun ke atas. Kelompok usia di bawah 25 tahun memiliki sikap yang negatif terhadap kewajiban untuk menggunakan helm ketika mengendarai sepeda motor. Mereka juga merasa kurang perlu untuk menggunakan helm. Kelompok usia di bawah 25 tahun juga mempersepsikan kurang adanya dukungan dari lingkungan atau orang-orang yang bermakna dalam hidup mereka, seperti orangtua, teman dan kenalan tentang pentingnya penggunaan helm $((t(132)=-$ $2,182 ; p=0.03)$ ). Pihak yang dipersepsikan memberi pengaruh adalah polisi yang akan menilang jika tidak menggunakan helm. Selain itu, kelompok usia di bawah 25 tahun juga 
mempersepsikan dirinya kurang memiliki kontrol untuk menentukan penggunaan helm $(t(132)=-2,079, p=0,04)$. Mereka cenderung menggunakan helm jika kondisi jalan yang akan ditempuh berbahaya.

Analisis regresi untuk faktor demografis menunjukkan bahwa variabel pendidikan mampu memprediksi perilaku menggunakan helm secara signifikan $(F(1,132)=10,460 ; p=0, .002)$, sedangkan faktor usia tidak signifikan untuk memprediksi penggunaan helm. Untuk dimensi faktor sosial psikologis, analisis multiple regression menunjukkan bahwa faktor utama yang dapat meramalkan penggunaan helm adalah dimensi sikap. Dimensi norma subjektif dan kontrol diri (PBC) ternyata tidak menjadi faktor penentu yang signifikan terhadap penggunaan helm. Hasil analisis juga menunjukkan bahwa secara keseluruhan ketiga dimensi faktor sosial psikologis tersebut menyumbang terhadap varians penggunaan helm sebesar 23,9 persen $\left(R^{2}=0,239\right)$.

\section{Analisis Kualitatif}

Dari pelaksanaan $F G D$ terhadap 11 orang diperoleh hasil bahwa faktor pendorong yang paling utama untuk menggunakan helm pada pengendara sepeda motor adalah keberadaan polisi, karena para partisipan takut untuk ditilang polisi jika tidak memakai helm. Alasan lain adalah untuk keselamatan dan kenyamanan, yaitu tidak terkena panas dan polusi udara. Bagi anak muda, penggunaan helm dipersepsikan sebagai gaya (fashion). Anak muda menjadi trend setter.

Faktor yang dipandang menghambat untuk menggunakan helm adalah jika helm sedang basah, gerah jika helmnya menutup muka secara penuh, dan apabila jarak lokasi yang hendak dituju dekat. Dalam pandangan partisipan, ketika tempat tujuan dekat dan bisa dicapai melalui jalan-jalan yang kecil, risiko untuk terjadinya kecelakaan kecil.

Faktor sosial budaya menurut partisipan juga berperan dalam menentukan penggunaan helm. Di beberapa daerah tidak terlihat adanya kebiasaan masyarakatnya untuk menggunakan helm di jalan. Para partisipan berpendapat bahwa atribut ormas dan keagamaan sering digunakan sebagai alasan tidak menggunakan helm. Sebagai contoh adalah pemakaian kopiah atau sorban. Figur otoritas, seperti polisi dan tokoh agama, yang tidak menggunakan helm di jalan adakalanya suka ditiru oleh masyarakat.

Menurut partisipan, anjuran menggunakan helm yang dibentuk ketika belajar mengendarai sepeda motor penting artinya untuk membentuk kebiasaan menggunakan helm dan membentuk kesadaran akan pentingnya menggunakan helm bagi keselamatan. Harga helm jug cukup terjangkau, yaitu sekitar Rp 200.000,-. Model helm yang memenuhi standar nasional Indonesia (SNI) juga sudah cukup bagus kualitasnya. Pilihan warnapun cukup banyak. Bahkan partisipan enggan membeli dan membawa helm yang bagus karena tidak aman untuk menyimpan di sepeda motor ketika mereka parkir.

Ketika ditanyakan tentang ketertiban penggunaan helm oleh masyarakat, sebagian partisipan setuju bahwa penggunaan helm di Depok cukup bagus, terutama di jalan Margonda. Gambaran ketertiban penggunaan helm kurang bagus di daerah perumahan dan di daerah pinggiran kota. Untuk meningkatkan ketertiban diperlukan upaya sosialisasi, menata isi pesan dalam iklan, memasang tanda menggunakan helm pada jalan-jalan kecil maupun jalan besar, dan menjaga kerahasiaan kapan dan di mana polisi akan melakukan razia. 


\section{KESIMPULAN}

Penggunaan helm oleh pengendara sepeda motor bergantung pada tempat, lingkungan, dan jenis pekerjaan. Di tempat yang ada polisi yang aktif melakukan razia, di lingkungan budaya yang mendukung, dan di lingkungan jalan yang dipersepsikan berbahaya, penggunaan helm cenderung tertib.

Figur otoritas merupakan hal yang juga dapat mempengaruhi perilaku menggunakan helm. Tokoh agama atau polisi cenderung menjadi panutan oleh masyarakat dalam menggunakan helm. Bagi kelompok dewasa muda, helm sudah menjadi bagian gaya (trend setter).

Dari sisi internal pengendara sepeda motor, penggunaan helm dapat diprediksi oleh jenis pekerjaan yang dimiliki. Jenis pekerjaan sebagai mahasiswa atau sebagai karyawan tampaknya menumbuhkan kesadaran tentang pentingnya penggunaan helm. Hal ini juga didukung oleh hasil $F G D$ yang menyatakan bahwa pengendara sepeda motor yang memiliki pekerjaan di kantoran pada umumnya sudah menggunakan helm.

Selain jenis pekerjaan, dimensi sikap menunjukkan peran yang besar dalam menentukan penggunaan helm. Sikap positif tentang kewajiban menggunakan helm di jalan dan persepsi tentang perlunya memakai helm menjadi keyakinan yang membedakan antara kelompok usia muda dan usia menengah. Kesadaran akan pentingnya menggunakan helm dan kebiasaan untuk menggunakan helm merupakan hal penting yang perlu dibentuk sejak awal belajar mengendarai sepeda motor.

\section{REKOMENDASI}

Mengacu pada hasil penelitian yang mendapatkan bahwa sikap merupakan dimensi yang paling berperan dalam memprediksi perilaku menggunakan helm, dan sikap itu sendiri berbeda antara usia di bawah 25 tahun dan usia di atas 25 tahun. Karena itu implimentasi temuan ini adalah mengarahkan upaya keras untuk melakukan sosialisasi tentang manfaat penggunaan helm kepada kelompok usia di bawah 25 tahun. Kepada mereka perlu diberikan informasi konkrit tentang pentingnya penggunaan helm bersamaan waktunya dengan saat mereka belajar mengendara motor. Hal ini akan membentuk kesadaran dan kebiasaan serta sikap yang positif terhadap penggunaan helm.

Pendekatan yang dapat dilakukan untuk menumbuhkan kesadaran dan sikap positif, antara lain, adalah dengan menggunakan tokoh idola usia muda yang sedang mengendarai sepeda motor dan menggunakan helm, mengaktifkan tokoh masyarakat, termasuk polisi, untuk memberi contoh secara konsisten menggunakan helm, dan menjadikan komunitas motor sebagai media untuk mempopulerkan penggunaan helm.

\section{DAFTAR PUSTAKA}

Badan Pusat Statistik. Perkembangan Jumlah Kendaraan Bermotor Menurut Jenis, 19492016. https://www.bps.go.id/linkTableDinamis/view/id/1133

Brijs, K., Brijs, T., Sann, S. A., Trinh, T., Wets, G., \& Ruiter, R.A.C. (2014). Psychological determinants of motorcycle helmet use among young adults in Cambodia. Transportation Research Part F: Traffic Psychology and Behaviour, 26, 273-290. 
Faryabi, J, Rajabi, M., Alirezaee. 2014. Evaluation of the use and reasons for not using a helmet by motorcyclists Admitted to the Emergency Ward of Shahid Bahonar Hospital in Kerman. Arch Trauma Res, 3(3): e19122. doi: [10.5812/atr.19122]

John, A. \& Najafi, F.Z. 2011. Influential Factors of Bicycle Helmet Use A Case Study of the University of Florida in Alachua County. ASEE Southeast Section Conference http://se.asee.org/proceedings/ASEE2011/Papers/FP2011naj159_171.PDF

Mirhossini , S.N., Davoodi , S.R, Azimmohseni, M. 2018. Intrinsic motivation and psychological factors on wearing helmet among motorcyclists in Gorgan City, Iran, in 2016. JOHE, 7(2):90-6

Nayazri, G.M. 2018. Korban Jiwa Tanpa Helm dan "Ngebut" Mendominasi 2017. Kompas.com - 15/05/2018, 08:23 WIB. https://otomotif.kompas.com/read/2018/05/15/082300415/korban-jiwa-tanpa-helmdan-ngebut-mendominasi-2017.

Sukor, N.S.A. \& Fujii, S. 2011. The Effect of Psychological Factors towards Motorcyclists' Risky Behaviours in Different Type of Motorcycle Lanes. International Journal of Humanities and Social Sciences, 1(9), 105-113

Suwannaporn, S., Hongsranagon, P., Havanond, P. 2013. Knowledge, Attitude, And Practice Towards Helmet Use Among Motorcycle Riders And Passengers In Ratchaburi Province, Thailand. J Health Res, 27(1), 27-32

https://paryadi.com/2018/01/16/jumlah-kendaraan-2018/. Wow jumlah kendaraan mencapai 111 juta di tahun 2018. 